\title{
PENDIDIKAN BUDAYA DAN KARAKTER
}

\author{
Oleh \\ I Wayan Sugita \\ Dosen Pendidikan Agama IHDN Denpasar
}

\begin{abstract}
ABSTRAK
Pendidikan nasional Indonesia saat ini masih menghadapi berbagai masalah. Capaian hasil pendidikan masih belum memenuhi hasil yang diharapkan. Pembelajaran di sekolah belum mampu membentuk secara utuh pribadi lulusan yang mencerminkan karakter dan budaya bangsa. Proses pendidikan masih menitikberatkan dan memfokuskan capaiannya secara kognitif. Sementara, aspek afektif pada diri peserta didik yang merupakan bekal kuat untuk hidup di masyarakat belum dikembangkan secara optimal. Karena itu, pendidikan karakter dan budaya bangsa merupakan seatu keniscayaan untuk dikembangkan di sekolah. Sekolah sebagai pusat perubahan perlu mengupayakan secara sungguh-sungguh pendidikan yang berbasis karakter dan budaya bangsa. Karakter dan budaya bangsa yang dikembangkan di sekolah harus diselaraskan dengan karakter dan budaya lokal, regional, dan nasional. Untuk itu, pendidikan karakter dan budaya bangsa perlu dikembangkan berdasarkan kearifan lokal.
\end{abstract}

\section{Kata Kunci:}

ABSTRACT

The current Indonesian national education still faces various problems. The education achievement is still below the expected target. The teaching and learning process at school has not been able to shape the graduates as whole persons who reflect the character and the culture of the nation. The education process still emphasizes andfocuses its outcome on the cognitive aspects. Meanwhile, the affective aspects of the learners which will become the strong basis to live in the community have not been developed optimally. Therefore, education on character and the culture of the nation must be developed at school. The school as the center of change must make serious efforts to provide education based on the character and the culture of the nation. The character and culture of the nation developed at school must be adjusted to the local, regional, and national character and culture. Hence, education on the character and culture of the nation should be developed based on the local wisdom.

\section{Keywords:}

\section{PENDAHULUAN}

Dunia pendidikan saat ini masih menampung banyak masalah. Program pemerataan dan peningkatan kualitas pendidikan belum menampakkan hasil seperti yang diharapkan. Jumlah anak usia pendidikan dasar yang berada di luar sistem pendidikan nasional masih sangat besar. Kualitas pendidikan pun masih relatif rendah.
Di pihak lain, tantangan di berbagai bidang kehidupan semakin berat. Perkembangan ilmu pengetahuan dan teknologi, khususnya di bidang informasi, komunikasi, dan transportasi sangat pesat, eskalasi pasar bebas antarnegara dan bangsa semakin meningkat, dan iklim kompetisi di berbagai aspek kehidupan semakin ketat. Masih banyak lagi masalah lain yang memerlukan penyelesaian 
seperti demokratisasi, hak asasi manusia, serta penyelenggaraan kehidupan bermasyarakat, berbangsa, dan bernegara yang adil dan terbuka. Dunia pendidikan harus mampu berperan aktif menyiapkan sumber daya manusia terdidik yang mampu menghadapi berbagai tantangan kehidupan, baik lokal, regional, nasional maupun internasional. Ia tidak cukup hanya menguasai teori-teori, tetapi juga mau dan mampu menerapkannya dalam kehidupan sosial. Ia tidak hanya mampu menerapkan ilmu yang diperoleh di bangku sekolah/kuliah, tetapi juga mampu memecahkan berbagai persoalan yang dihadapi dalam kehidupan sehari-hari.

Sumber Daya Manusia yang berkarakter sebagaimana diungkapkan di atas dapat dicapai melalui pendidikan yang berorientasi pada pembentukan jiwa entrepreneurship, yaitu jiwa keberanian dan kemauan menghadapi problema hidup dan kehidupan secara wajar, jiwa kreatif untuk mencari solusi dan mengatasi problema tersebut, dan jiwa mandiri dan tidak bergantung pada orang lain. Salah satu jiwa entrepreneurship yang perlu dikembangkan melalui pendidikan adalah karakter yang bersumber dari budaya bangsa.

Pendidikan yang berbasis karakter dan budaya bangsa adalah pendidikan yang menerapkan prinsip-prinsip dan metodologi ke arah pembentukan karakter anak bangsa pada peserta didiknya melalui kurikulum terintegrasi yang dikembangkan di sekolah. Kerangka pengembangan karakter dan budaya bangsa melalui pembelajaran di kalangan tenaga pendidik dirasakan sangat penting. Sebagai agen perubahan, pendidik diharapkan mampu menanamkan ciri-ciri, sifat, dan watak serta jiwa mandiri, tanggung jawab, dan cakap dalam kehidupan kepada peserta didiknya. Di samping itu, karakter tersebut juga sangat diperlukan bagi seorang pendidik karena melalui jiwa ini, para pendidik akan memiliki orientasi kerja yang lebih efisien, kreatif, inovatif, produktif serta mandiri.

\section{PENTINGNYA PENDIDIKAN KARAKTER DAN BUDAYA BANGSA}

Pendidikan saat ini hanya menge depankan penguasaan aspek keilmuan dan kecerdasan peserta didik. Jika peserta didik sudah mencapai nilai atau lulus dengan nilai akademik memadai/di atas KKM (Kriteria Ketuntasan Minimal), pendidikan dianggap sudah berhasil. Pembentukan karakter dan nilai-nilai budaya bangsa di dalam diri peserta didik semakin terpinggirkan. Rapuhnya karakter dan budaya dalam kehidupan berbangsa bisa membawa kemunduran peradaban bangsa. Padahal, kehidupan masyarakat yang memiliki karakter dan budaya yang kuat akan semakin memperkuat eksistensi suatu bangsa dan negara. Pengembangan pendidikan berbasis karakter dan budaya bangsa perlu menjadi program nasional. Dalam pendidikan, pembentukan karakter dan budaya bangsa pada peserta didik tidak harus masuk kurikulum. Nilai-nilai yang ditumbuhkembangkan dalam diri peserta didik berupa nilai-nilai dasar yang disepakati secara nasional. Nilai-nilai yang dimaksudkan di antaranya adalahkejujuran, dapat dipercaya, kebersamaan, toleransi, tanggung jawab, dan peduli kepada orang lain.

Franz Magnis-Suseno, dalam acara Sarasehan Nasional Pengembangan Pendidikan Budaya dan Karakter Bangsa (14/01/2010) mengatakan bahwa pada era sekarang ini yang dibutuhkan bukan hanya generasi muda yang berkarakter kuat, Pengembangan Pendidikan Karakter dan Budaya Bangsa Berwawasan Kearifan Lokal tetapi juga benar, positif, dan konstruktif. Namun, untuk membentuk peserta didikpeserta didik yang berkarakter kuat, tidak boleh ada feodalisme para pendidik. Jika pendidik membuat peserta didik menjadi "manutan" (obedient) dengan nilai-nilai penting, tenggang rasa, dan tidak membantah, karakter peserta didik tidak akan berkembang. Kalau kita mengharapkan karakter, peserta 
didik itu harus diberi semangat dan didukung agar ia menjadi pemberani, berani mengambil inisiatif, berani mengusulkan alternatif, dan berani mengemukakan pendapat yang berbeda. Kepada peserta didik, perlu diajarkan cara berpikir sendiri. Untuk pengembangan pendidikan berbasis karakter dan budaya bangsa, dibutuhkan masukan, antara lain, menyangkut model-model pengembangan karakter dan budaya bangsa sebagai bagian yang tidak terpisahkan dari sistem pendidikan nasional. Kebutuhan terus harus dimaknai serius karena memerlukan banyak pengorbanan.

Kerisauan dan kerinduan banyak pihak untuk kembali memperkuat pendidikan karakter dan budaya bangsa perlu direspons dengan baik. Karena itu, data akurat yang menyangkut model-model pengembangan karakter dan budaya bangsa perlu digali dan dilaksanakan melalui kajian empiris, yakni kegiatan penelitian. Syarat menghadirkan pendidikan karakter dan budaya bangsa di sekolah harus dilakukan secara holistis. Pendidikan karakter tidak bisa terpisah dengan bentuk pendidikan yang sifatnya kognitif atau akademik. Konsep pendidikan tersebut harus diintegrasikan ke dalam kurikulum. Hal ini tidak berarti bahwa pendidikan karakter akan diterapkan secara teoretis, tetapi menjadi penguat kurikulum yang sudah ada, yaitu dengan mengimplementasikannya dalam mata pelajaran dan keseharian peserta didik didik.

\section{KARAKTER PESERTA DIDIK YANG DIHARAPKAN}

Karakter dapat diartikan sebagai bawaan, hati, jiwa, kepribadian, budi pekerti, perilaku, personalitas, sifat, tabiat, temperamen, dan watak. Karakter dalam pengertian ini menandai dan memfokuskan pengaplikasian nilai kebaikan dalam bentuk tindakan atau tingkahlaku. Orang yang tidak mengaplikasikan nilai-nilai kebaikan, misalnya tidak jujur, kejam, rakus, dan perilaku jelek lainnya dikatakan orang yang berkarakter jelek, tetapi orang yang perilakunya sesuai dengan kaidah moral disebut dengan berkarakter mulia.

Karakter peserta didik yang dimaksudkan dalam tulisan ini adalah karakter mulia yang diharapkan dapat dikembangkan kepada peserta didik. Dalam hal ini, membangun karakter peserta didik mengarah pada pengertian tentang mengembangkan peserta didik agar memiliki kepribadian, perilaku,sifat, tabiat, dan watak baik atau mulia. Karakter yang demikan ini mengacu pada serangkaian sikap, perilaku, motivasi, dan kecakapan yang memenuhi standar nilai dan norma yang dijunjung tinggi dan dipatuhi. Peserta didik yang memiliki karakter mulia memiliki pengetahuan tentang potensi dirinya, yang ditandai dengan nilai-nilai seperti reflektif, percaya diri, rasional, logis, kritis, analitis, kreatif dan inovatif, mandiri, hidup sehat, bertanggung jawab, cinta ilmu, sabar, berhati-hati, rela berkorban, pemberani, dapat dipercaya, jujur, menepati janji, adil, rendah hati, malu berbuat salah, pemaaf, berhati lembut, setia, bekerja keras, tekun, ulet/gigih, teliti, berinisiatif, berpikir positif, disiplin, antisipatif, inisiatif, visioner, bersahaja, bersemangat, dinamis, hemat/efisien, menghargai waktu, pengabdian/dedikatif, pengendalian diri, produktif, ramah, cinta keindahan (estetis), sportif, tabah, terbuka, tertib. Di samping itu, individu juga memiliki kesadaran untuk berbuat yang terbaik atau unggul dan mampu bertindak sesuai potensi dan kesadarannya tersebut. Mereka dapat merealisasikan perkembangan positif sebagai individu (intelektual, emosional, sosial, etika, dan perilaku).Peserta didik yang berkarakter baik atau unggul selalu berusaha melakukan hal-hal yang terbaik terhadap Tuhan, dirinya, sesama, lingkungan, bangsa dan negara serta dunia internasional pada umumnya dengan 
mengoptimalkan potensi (pengetahuan) dirinya dan disertai dengan kesadaran,emosi dan motivasinya (perasaannya).

Keberhasilan program pendidikan karakter dapat diketahui melalui pencapaian indikator oleh peserta didik sebagaimana tercantum dalam standar kompetensi lulusan (SKL), yang antara lain meliputi sebagai berikut. 1) Mengamalkan ajaran agama yang dianut sesuai dengan tahap perkembangan remaja. 2) Memahami kekurangan dan kelebihan diri sendiri. 3) Menunjukkan sikap percaya diri. 4) Mematuhi aturan-aturan sosial yang berlaku dalam lingkungan yang lebih luas. 5) Menghargai keberagaman agama, budaya, suku, ras, dan golongan sosial ekonomi dalam lingkup nasional. 6) Mencari dan menerapkan informasi dari lingkungan sekitar dan sumber-sumber lain secara logis, kritis, dan kreatif. 7) Menunjukkan kemampuan berpikir logis, kritis, kreatif, dan inovatif. 8) Menunjukkan kemampuan belajar secara mandiri sesuai dengan potensi yang dimilikinya. 9) Menunjukkan kemampuan menganalisis dan memecahkan masalah dalam kehidupan sehari-hari. 10) Mendeskripsikan gejala alam dan sosial. 11) Memanfaatkan lingkungan secara bertanggung jawab. 12) Menerapkan nilai-nilai kebersamaan dalam kehidupan bermasyarakat, berbangsa, dan bernegara demi terwujudnya persatuan dalam negara kesatuan Republik Indonesia. 13) Menghargai karya seni dan budaya nasional.14) Menghargai tugas pekerjaan dan memiliki kemampuan untuk berkarya. 15) Menerapkan hidup bersih, sehat, bugar, aman, dan memanfaatkan waktu luang dengan baik. 16) Berkomunikasi dan berinteraksi secara efektif dan santun. 17) Memahami hak dan kewajiban diri dan orang lain dalam pergaulan di masyarakat; menghargai adanya perbedaan pendapat. 18) Menunjukkan kegemaran membaca dan menulis naskah pendek sederhana. Menunjukkan keterampilan menyimak, berbicara, membaca, dan menulis dalam bahasa Indonesia dan bahasa Inggris sederhana. 19) Menguasai pengetahuan yang diperlukan untuk mengikuti pendidikan menengah. 20) Memiliki jiwa kewirausahaan.

\section{PENDIDIKAN BERBASIS KARAKTER DAN BUDAYA BANGSA}

Pada hakikatnya, pendidikan karakter merupakan suatu sistem pendidikan yang berupaya menanamkan nilai-nilai luhur Pengembangan Pendidikan Karakter dan Budaya Bangsa Berwawasan Kearifan Lokal kepada warga sekolah yang meliputikomponen pengetahuan, kesadaran atau kemauan, dan tindakan untuk melaksanakan nilai-nilai tersebut. Dalam pelaksanaan pendidikan karakter di sekolah, semua komponen sekolah harus dilibatkan, termasuk komponenkomponen pendidikan itu sendiri, yaitu isi kurikulum, proses pembelajaran dan penilaian, penanganan atau pengelolaan mata pelajaran, pengelolaan sekolah, pelaksanaan aktivitas atau kegiatan kokurikuler, pemberdayaan sarana prasarana, pembiayaan, dan etos kerja seluruh warga sekolah/lingkungan.

Dalam pendidikan karakter dan budaya bangsa ini, segala sesuatu yang dilakukan guru harus mampu mempengaruhi karakter peserta didik. Sebagai pembentuk watak peserta didik, guru harus menunjukkanketeladanan. Segala hal tentang perilaku guru hendaknya menjadi contoh bagi peserta didik. Misalnya, cara guru berbicara atau menyampaikan materi, cara guru bertoleransi, dan berbagai hal terkait lainnya. Tujuannya adalah membentuk pribadi anak agar menjadi manusia yang baik, warga masyarakat, dan warga negara yang baik.

Kriteria manusia yang baik, warga masyarakat yang baik, dan warga negara yang baik bagi suatu masyarakat atau bangsa, secara umum didasarkan pada nilai-nilai sosial tertentu, yang banyak dipengaruhi oleh budaya masyarakat dan bangsanya. Oleh karena itu, hakikat pendidikan karakter dan budaya bangsa dalam konteks pendidikan adalah 
pendidikan nilai, yakni pendidikan nilai-nilai luhur yang bersumber dari budaya bangsa sendiri, dalam rangka membina kepribadian generasi muda. Pendidikan karakter berpijak dari karakter dasar manusia, yang bersumber dari nilai moral universal (bersifat absolut) yang disebut sebagai kaidah emas (the golden rule). Pendidikan karakter dapat memiliki tujuan yang pasti apabila berpijak dari nilainilai karakter dasar sebagaimana diungkapkan di atas. Penyelenggaraan pendidikan karakter di sekolah harus berpijak pada nilai-nilai karakter dasar, yang selanjutnya dikembangkan menjadi nilai-nilai yang lebih banyak atau lebih tinggi (yang bersifat tidak absolut atau bersifat relatif) sesuai dengan kebutuhan, kondisi, dan lingkungan sekolah itu sendiri (Sudrajad, 2010).

Dewasa ini, banyak pihak menuntut peningkatan intensitas dan kualitas pelaksanaan pendidikan karakter pada lembaga pendidikan formal. Tuntutan tersebut didasarkan pada fenomena sosial yang berkembang, yakni meningkatnya kenakalan remaja dalam masyarakat, seperti perkelahian massal dan berbagai kasus dekadensi moral lainnya. Bahkan, di kota-kota besar tertentu, gejala tersebut telah sampai pada taraf yang sangat meresahkan. Oleh karena itu, lembaga pendidikan formal sebagai wadah resmi pembinaan generasi muda diharapkan dapat meningkatkan peranannya dalam pembentukan kepribadian peserta didik melalui peningkatan intensitas dan kualitas pendidikan karakter.

Para pakar pendidikan pada umumnya sependapat tentang pentingnya upaya peningkatan pendidikan karakter pada jalur pendidikan formal. Namun, juga terdapat perbedaan pendapat di antaranya mengenai pendekatan dan modus pendidikan. Berkaitan dengan pendekatan, sebagian pakar menyarankan penggunaan pendekatan-pendekatan pendidikan moral yang dikembangkan di negara-negara barat, seperti: pendekatan perkembangan moral kognitif, pendekatan analisis nilai, dan pendekatan klarifikasi nilai. Sebagian yang lain menyarankan penggunaan pendekatan tradisional, yakni melalui penanaman nilainilai sosial tertentu dalam diri peserta didik. Secara psikologis dan sosial kultural pembentukan karakter dalam diri individu merupakan fungsi dari seluruh potensi individu manusia (kognitif, afektif, konatif, dan psikomotorik) dalam konteks interaksi sosial kultural (dalam keluarga, sekolah, dan masyarakat) dan berlangsung sepanjang hayat. Konfigurasi karakter dalam konteks totalitas proses psikologis dan sosial kultural tersebut dapat dikelompokkan dalam: olah hati (spiritual and emotional development), olah pikir (intellectual development), olah raga dan kinestetik (physical and kinestetic development), danolahrasa dankarsa(affective and creativity development). Berdasarkan pembahasan di atas, dapat ditegaskan bahwa pendidikan karakter merupakan upaya yang dirancang dan dilaksanakan secara sistematis untuk membantu peserta didik memahami nilai-nilai perilaku manusia yang berhubunga $\mathrm{n}$ dengan Tuhan, diri sendiri, sesama manusia, lingkungan, dan kebangsaan yang terwujud dalam pikiran, sikap, perasaan, perkataan, dan perbuatan berdasarkan norma-norma agama, hukum, tata krama, budaya, dan adat istiadat. Menurut Foerster (Koesoema, 2010), terdapat empat ciri dasar dalam pendidikan karakter.

Keempat ciri tersebut sebagai berikut. 1) Pertama adalah keteraturan interior. Setiap tindakan diukur berdasarkan hierarki nilai. Nilai menjadi pedoman normatif setiap tindakan. 2) Kedua adalah koherensi yang memberi keberanian, membuat seseorang teguh pada prinsip, tidak mudah terombangambing pada situasi baru atau takut resiko. Koherensi merupakan dasar yang membangun rasa percaya satu sama lain. Tidak adanya koherensi meruntuhkan kredibilitas seseorang. 3) Ketiga adalah otonomi. Seseorang 
menginternalisasikan aturan dari luar sampai menjadi nilai-nilai bagi pribadi.

Hal ini dapat dilihat lewat penilaian atas keputusan pribadi, tanpa terpengaruh atau desakan pihak lain. 4) Keempat adalah keteguhan dan kesetiaan. Keteguhan merupakan daya tahan seseorang guna mengingini apa yang dipandang baik dan kesetiaan merupakan dasar bagi penghormatan atas komitmen yang dipilih. Kematangan keempat karakter ini memungkinkan manusia melewati tahap individualitas menuju personalitas. Orang-orang modern sering mencampuradukkan antara individualitas dan personalitas, antara aku alami dan aku rohani, antara independensi eksterior dan interior. Karakter inilah yang menentukan performansi seorang pribadi dalam segala tindakannya.

\section{MEMBANGUN PENDIDIKAN KARAKTER BERBASIS KEARIFAN LOKAL}

Era saat ini adalah era global. Untuk menghadapi era global ini, diperlukan insan bermoral, kompeten, dan unggul. Dalam hal ini, pendidikan merupakan upaya yang paling strategis. Sistem pendidikan nasional dalam batas tertentu telah menghasilkan insan yang berkualitas, missalnya sejumlah orang yang dipercaya untuk menduduki posisi strategis di semua sektor dan di tengah-tengah masyarakat. Namun, patut diakui bahwa masih banyak pernyataan yang mengindikasilkan sistem pendidikan kita ikut andil akan rendahnya kualitas sumberdaya manusia dan masih merebaknya dekadensi moral yang berdampak terhadap krisis multidimensional.

Untuk meminimalisasi dan memperkecil, bahkan menghilangkan krisis multidemensional, terutama perilaku tak bermoral yang meluas di masyarakat, kita perlu menata konsep dan implementasi pendidikan nasional. Dalam menjamin pendidikan nasional yang mantap, perlu dijaga konsistensi pendidikan karakter sejak dari landasan filosofis, sistem pendidikan, sampai dengan praktik pendidikan. Tujuan pendidikan tidak hanya menjadikan insan berakal, insan kompeten dan berguna, insan well adaptive, insan agent of change, dan insan bertaqwa, melainkan insan yang utuh (Wahab, 2010). Dalam proses pendidikan, peserta didik dipandang sebagai individu yang memiliki potensi moral, mental, fisik, sosial, dan emosional dengan keunikannya.

Mereka sebagai co subject object yang memiliki kebebasan memilih. Karena itu, kurikulum pendidikan tidak hanya berupa kurikulum yang bererientasi pada peseta didik, masyarakat, atau pengetahuan dan teknologi, tetapi merupakan kurikulum eklektik dan komprehensif yang mencakup keempat ranah tersebut (student, society, technology, and spiritual oriented curriculum). Dalam membangun dan menanamkan budaya bangsa kepada peserta didik, pendidik dan tenaga kependidikan menjadi agen perubahan. Guru tidak hanya kompeten, tetapi juga menjadi teladan (sikap, pikiran, dan perilaku), kreatif, dan well adaftif (profesional yang utuh). Demikian juga, ia mengupayakan terus untuk peningkatan diri.

Konselor harus benar-benar profesional, yang selalu siap untuk membantu pengembangan diri peserta didik secara optimal dalam melakukan aktualisasi diri. Kepala sekolah harus memiliki principle leadership, disiplin, model, dan supervisonship skill. Kinerja pustakawan dan laboran/teknisi harus memliki jiwa dan sikap yang helpfull. Di samping itu, dalam pelaksanaan pendidikan, harus tersedia ahli terkait (psikolog, dokter) yang ramah dan suka membantu. Pengelolaan pendidikan perlu diupayakan prinsip keadilan, kebermaknaan, dan keberamahan pada lingkungan. Pengelolaan pendidikan yang demikian dapat diupayakan melalui pendidikan yang berbasis sekolah dan berbasis 
masyarakat (sadar nilai) dengan pertimbangan balanced centralization-decentralization yang tetap menempatkan kepentingan daerah.

Proses pendidikan dilakukan secara terpadu dengan menjadikan spiritualitas sebagai ruhnya. Dalam pembelajaran, perlu dilakukan penambahan durasi waktu efektif belajar sebagai konsekuensi logis orientasi keluaran (output) yang unggul. Di samping itu, pengelolaan pendidikan harus dilakukan secara transparan, adil, dan akun tabel. Untuk itu, dalam proses pendidikan perlu dilibatkan orang tua dan masyarakat, baik dalam aspek akademik, maupun aspek nonakademik (terutama aspek moralitas). Dalam penilaian pendidikan, tidak hanya difokuskan pada hasil pendidikan, tetapi juga kepada masukan (input ) dan proses (penilaian komprehensif). Penilaian pendidikan tidak hanya pada aspek akademik, tetapi juga aspek nonakademik (terutama moral menjadi penentu). Karena itu, penilaian pendidikan sebaiknya tidak hanya dilakukan oleh guru, melainkan juga peserta didik, pendidik dan tenaga kependidikan lainnya, bahkan jika mungkin melibatkan orang tua. Dalam kegiatan penilaian, tidak hanya dilakukan hanya untuk kepentingan yang bersifat judgmental, tetapi juga bersifat apresiatif dan rekognitif.

Dalam membangun karakter budaya bangsa, lingkungan pendidikan harus mengarah pada penciptaan lingkungan keluarga yang sarat dengan nilai (agama, budaya, dan kebangsaan). Kehidupan di ingkungan sekolah harus mengupayakan lingkungan sekolah yang kondusif bagi pengembangan nilai. Dalam hal ini, sekolah harus mampu mengondisikan lingkungan masyarakat dengan nilai-nilai yang baik dan mengendalikannya dengan memainkan peran filter terhadap nilai-nilai asing yang masuk. Di samping itu,pemangku kepentingan pendidikan harus dapat mengawal isi media masa yang memberikan manfaat bagi penyebaran nilai-nilai dan mengendalikan isi media masa yang berpotensi merusak kepribadian anak dan bangsa.

Dalam melaksanakan pendidikan berbasis karakter dan budaya bangsa, strategi pengembangan pendidikan perlu mengonseptualisasikan individu sebagai makhluk utuh dengan menekankan penting nya aspek moral. Proses pendidikan harus diupayakan untuk pendidikan nilai sedini mungkin dan sepanjang hayat. Program pendidikan dan kurikulum harus dikembangkan secara terpadu sesuai dengan latar belakang sosial budaya dengan menempatkan nilai moral menjadi ruhnya. Aktivitas keseharian harus menempatkan pimpinan institusi dan pendidik menjadi model dan bertindak adil, amanah, dan kasih sayang. Pembelajaran hendaknya mampu menciptakan gerakan pendidikan nilai dan mengawalnya secara berkesinambungan, baik dalam konteks pendidikan formal, informal, maupun non formal. Proses pendidikan hendaknya memberikan orientasi peserta didik baru dan melepas lulusan setiap jenjang pendidikan dengan materi nilai-nilai yang dapat diterima di masyarakat.

Agar peserta didik tidak tercerabut dari akar budayanya, pendidikan perlu menginternalisasikan nilai-nilai yang dijunjung tinggi di masyarakat selama dalam proses pembelajaran dan pendidikan dengan mengupayakan lingkungan fisik dan sosial yang bersih dan menarik.

\section{LINGKUNGAN SEBAGAI SUMBER PEMBELAJARAN KEARIFAN LOKAL}

Peserta didik sebagai manusia yang utuh memiliki potensi diri, baik sebagai pribadi maupun anggota masyarakat. Potensi diri tersebut akan dapat berkembang dengan baik jika diupayakan secara optimal melalui proses pendidikan. Melalui pendidikan ini, peserta didik akan dapat diarahkan menjadi sosok pribadi yang memiliki kompetensi majemuk sehingga dapat tumbuh dan berkembang 
menjadi anggota masyarakat yang mampu memecahkan persoalan hidupnya. Dalam hal ini, kunci utamanya adalah aktivitas pembelajaran di sekolah. Pertumbuhan dan perkembangan peserta didik melalui belajar tidak hanya terjadi di bangku sekolah yang terbatas oleh dinding-dinding kelas. Namun, proses pembelajaran bagi peserta didik dapat terjadi pula di lingkungan sekitar, yakni aktivitas peserta didik di luar kelas. Pembelajaran yang dikungkung di dalam kelas sering menciptakan kejenuhan pada diri peserta didik karena mereka merasa beada di dunia lain yang bukan dunianya. Di dalam kelas, peserta didik merasa kebebasannya dirampas, kesenangannya dibatasi, tertawanya semu, keinginannya dihambat. Akibatnya, kreativitas mereka terbatas pada upaya memenuhi dan menuruti kemauan sistem belajar yang dituntut sekolah. Peserta didik merindukan kembali ke lingkungannya yang telah menyatu sejak dini dalam keutuhan pribadi yang telah lama membentuknya.

Pembelajaran berbasis lingkungan dapat menjembatani peserta didik untuk menemukan kembali harapannya. Yang dimaksud pembelajaran berbasis. Pembelajaran Lingkungan Model Proyek MPL Proyek merupakan model pembelajaran terprogram yang memerlukan waktu agak panjang. Dalam proyek tersebut, diperlukan waktu agak lama karena peserta didik terlibat dalam kegiatan yang cukup kompleks. Peserta didik tidak sekedar melakukan pengamatan, tetapi juga melakukan kegiatan-kegiatan lainnya sebagai konsekuensi dari hasil pengamatan tersebut. Dalam proyek ini, mungkin sekali peserta didik menemukan berbagai persoalan dan berusaha untuk mencari jalan pemecahannya. Berdasarkan temuannya itu, peserta didik diminta untuk melakukan kegiatan seminar untuk menyampaikan berbagai problema yang dihadapi dan upaya pemecahannya. Karena itu, model pembelajaran ini dalam penggarapannya dapat dilakukan melalui proses konsultasi dan tutorial, yang selanjutnya dikembangkan dalam proyek seminar hasil pengamatan.

\section{PENUTUP}

Dalam pengembangan pendidikan karakter, diperlukan pemahaman bersama antara pemerintah, embaga pendidikan, pendidik (guru, orang tua), dan masyarakat mengenai pentingnya pembangunan karakter bangsa. Dalam aktivitas pembelajaran, guru/pendidik memiliki tugas mendesain kondisi pembelajaran sehingga membentuk lingkungan belajar yang menjamin terwujudnya pendidikan karakter.

Dalam hal ini, pembelajaran karakter harus terintegrasi, baik dalam budaya sekolah, kegiatan ekstrakurikuler, maupun kegiatan seharian di rumah dan di masyarakat.

Dalam pengembangan karakter, perlu diperhatikan bentuk-bentuk budaya bangsa (pemahaman tentang pengenalan diri, tujuan hidup, interaksi dengan orang-orang di sekitar, dan proses pengambilan putusan). Metode pengembangan pendidikan karakter dapat dilakukan dengan (a) proses penyadaran dan pembiasaan; (b) belajar melalui pengalaman; dan (c) menyesuaikan dengan karakteristik dan hak peserta didik. Pembentukan karakter bangsa memerlukan (a) peraturan yang membentuk suatu ulur yang menjaga integritas akademis lembaga pendidikan; (b) pengembangan kemampuan peserta didik untuk berpikir kritis agar menjadi pelajar yang mampu memaknai berbagai pengetahuan dan informasi secara baik dan bijak; dan (c) pengembangan desain sistem evaluasi akademik (tentang kenaikan dan kelulusan) yang mampu menjadi solusi alternatif sistem penilaian yang benar-benar mampu memotret kemampuan peserta didik.

Pembentukan karakter dimulai dari keinginan untuk mengetahui serta melakukan hal yang baik agar tercipta kebiasaan, baik di hati, pikiran, maupun perilaku. Dalam 
membentuk karakter positif, peserta didik perlu mengetahui alasan mengapa berbuat baik, merasakan hal yang baik, dan melakukan hal yang baik. Perlunya lingkungan belajar yang positif dan peduli yang ditandai dengan penuh kasih sayang, penuh dengan kepedulian, kompetensi guru dan staf sekolah yang memberikan inspirasi dan bebas dari berbagai bentuk tindak kekerasan, serta pendidikan yang inklusif.

\section{DAFTAR PUSTAKA}

APPI.2010.Rekomendasi Peran Pendidikan dalam Pembangunan Karakter Bangsa. Konferensi dan Workshop tentang Peran Pendidikan dalam Pembangunan Karakter Bangsa pada 16-17 Oktober 2010 di Universitas Negeri Malang (UM).

Budimansyah, D. 2007. "Pendidikan Demokrasi Sebagai Konteks Civic Education di Negara-negara Berkembang", Jurnal Acta Civicus, Vol.1 No.1, hlm.11-26.

Depdiknas. 2003.Undang-undang Sistem Pendidikan Nasional. Jakarta: Pusat Dokumentasi Depdiknas.

Depdiknas. 2005. Undang-undang Guru dan Dosen. Bandung: Adicita Karya Nusa.

Depdiknas. 2007.Pedoman Penilaian Guru dalam Jabatan.Jakarta: Direktorat Peningkatan Mutu Pendidik dan Tenaga Kependidikan.

Koesoema,Doni. 2010. Pendidikan Karakter. Roma: Fakultas Ilmu Pendidikan Universitas Kepausan Salesian.

Raka, I.I.D.G. 2008. Pembangunan Karakter dan Pembangunan Bangsa: Menengok Kembali Peran Perguruan Tinggi. Bandung: Majelis Guru Besar ITB.

Sudrajat, Akhmad.2010. "Tentang Pendidikan Karakter" (dalam http://akh-madsudrajat.wordpress. com/2010/08/20/pendidikan-karakterdismp) diakses 18 Oktober 2010.
Sudrajat, Akhmad.2010. "Indikator Keberhasilan Program Pendidikan Karakter" (dalam http://akhmadsudrajat. wordpress . com/2010/08/20/ pendidikan-karakter-di-smp/) diakses 18 Oktober 2010.

Sukarno.1965. Di Bawah Bendera Revolusi. Jakarta: Panitia Penerbit Di Bawah Bendera Revolusi.

Supriadi, Dedi. 1998.Mengangkat Citra dan Martabat Guru. Bandung: Adicita Karya Nusa.

Wahab,Rochmat. 2010. "Membangun Pendidikan Karakter Berbasis Kearifan Lokal" (dalam http://pagenjahan. blogspot.com/2010/07/makalahseminar-nasional-pendidikan-2.html) diakses 18 Oktober 2010.

Widodo, Rachmad. 2010. "Benarkah Pendidikan Kita Mengabaikan Pendidikan Karakter" (dalam http:// wyw1d.wordpress.com/2010/01/24/ b e narkah - pendidikan - kita mengabaikan-pendidikan-karakter/) diakses 18 Oktober 2010.

Winataputra, U.S. dan Budimansyah, D. 2007. Civic Education: Konteks, Landasan, Bahan Ajar, dan Kultur Kelas. Bandung: Program Studi Pendidikan Kewarganegaraan SPs UPI. 